\title{
First record of the Early Carboniferous ammonoid genus Goniatites from the Greater Karatau (Kazakhstan palaeocontinent)
}

\author{
Dieter Korn ${ }^{1,2} \cdot$ Zdzislaw Belka $^{3} \cdot$ Stanislaw Skompski ${ }^{4}$ Michal Jakubowicz ${ }^{3,4} \cdot$ Sezim Mustapaeva ${ }^{5}$. \\ Adilkhan Baibatsha ${ }^{5}$
}

Received: 13 November 2019 / Revised: 17 January 2020 / Accepted: 30 March 2020 / Published online: 24 July 2020

(C) The Author(s) 2020

\begin{abstract}
The Late Viséan ammonoid genus Goniatites had a near-global distribution within the tropical seas but was rarely reported from Central Asia. New investigations of the Early Carboniferous sedimentary succession in the Greater Karatau of Kazakhstan revealed a species-poor new assemblage with Goniatites and assists in the biostratigraphic subdivision of the section. The new species Goniatites zhankurganensis and G. abaiensis are described; these species have a morphological position at both ends of the morphological spectrum of the genus.
\end{abstract}

Keywords Ammonoidea $\cdot$ Goniatitidae $\cdot$ Carboniferous $\cdot$ Greater Karatau $\cdot$ Kazakhstan $\cdot$ Biogeography

\section{Introduction}

The genus Goniatites is the classic Early Carboniferous ammonoid genus and has a nearly worldwide distribution in the tropical zone (Korn et al. 2012). Its occurrences range from Alaska (Gordon Jr. 1957) across the American West (e.g. Korn and Titus 2011), the American Midcontinent (e.g. Gordon Jr. 1965; Drahovzal 1972), numerous localities in the North African, Western, North-Western and Central European parts of the North Variscan realm (e.g. Bisat 1934; Korn 1988, 1997b; Korn and Ebbighausen 2008; Korn 2017), the South Variscan Cantabrian Mountains (e.g. Kullmann

This article is registered in Zoobank under urn:lsid:zoobank.org:pub:C9DDC651-0C79-4EC3-9D07-951FA0356517

Dieter Korn

dieter.korn@mfn-berlin.de

1 Museum für Naturkunde, Leibniz-Institut für Evolutions- und Biodiversitätsforschung, Invalidenstraße, 43, 10115 Berlin, Germany

2 Nanjing Institute of Geology and Palaeontology, Chinese Academy of Sciences, 39 East Beijing Road, Nanjing, China

3 Isotope Laboratory, Adam Mickiewicz University, Krygowskiego 10, 61-680 Poznań, Poland

4 Institute of Geoecology and Geoinformation, Adam Mickiewicz University, ul. Krygowskiego 10, 61-680 Poznań, Poland

5 Kazakh National Technical University, Satpaev st. 22, Almaty, Kazakhstan 050013
1961), the North Gondwanan localities in North-Western Africa (e.g. Klug et al. 2006; Korn et al. 2007), the North Urals (Skompski et al. 2001), the South Urals (e.g. Bogoslovskaya 1966) to Xinjiang in North China (Liang and Wang 1991) and possibly to Queensland of Australia (Campbell et al. 1983).

Here we report on new findings of ammonoid specimens belonging to Goniatites in southern Kazakhstan. With these, we add another region to the near-global occurrences of Goniatites within the tropical Early Carboniferous seas. The assemblage has been discovered in the Zhankurgan section of the Greater Karatau Mountains (Fig. 1) in a series of intercalated shales with proximal limestone turbidites (Zhaimina et al. 2014).

\section{Geological and stratigraphic background}

The Greater Karatau Mountains is a part of the KazakhKyrgyz terrane, one of the continental terranes assembled within the accretionary-orogenic system of the Tian Shan (Tien Shan) belt (e.g. Filippova et al. 2001; Worthington et al. 2017). During the Devonian-Carboniferous times, this terrane constituted an individual microcontinent called the Kazakh-Kyrgyz, Kazakhstania or the Kazakhstan palaeoconti-nent (e.g. Abrajevitch et al. 2008; Alexeiev et al. 2009; Biske and Seltmann 2010). Its southwestern passive margin was formed by a 4500 m-thick carbonate platform of the Greater Karatau (Alexeiev et al. 2017). The seaward margin and the 


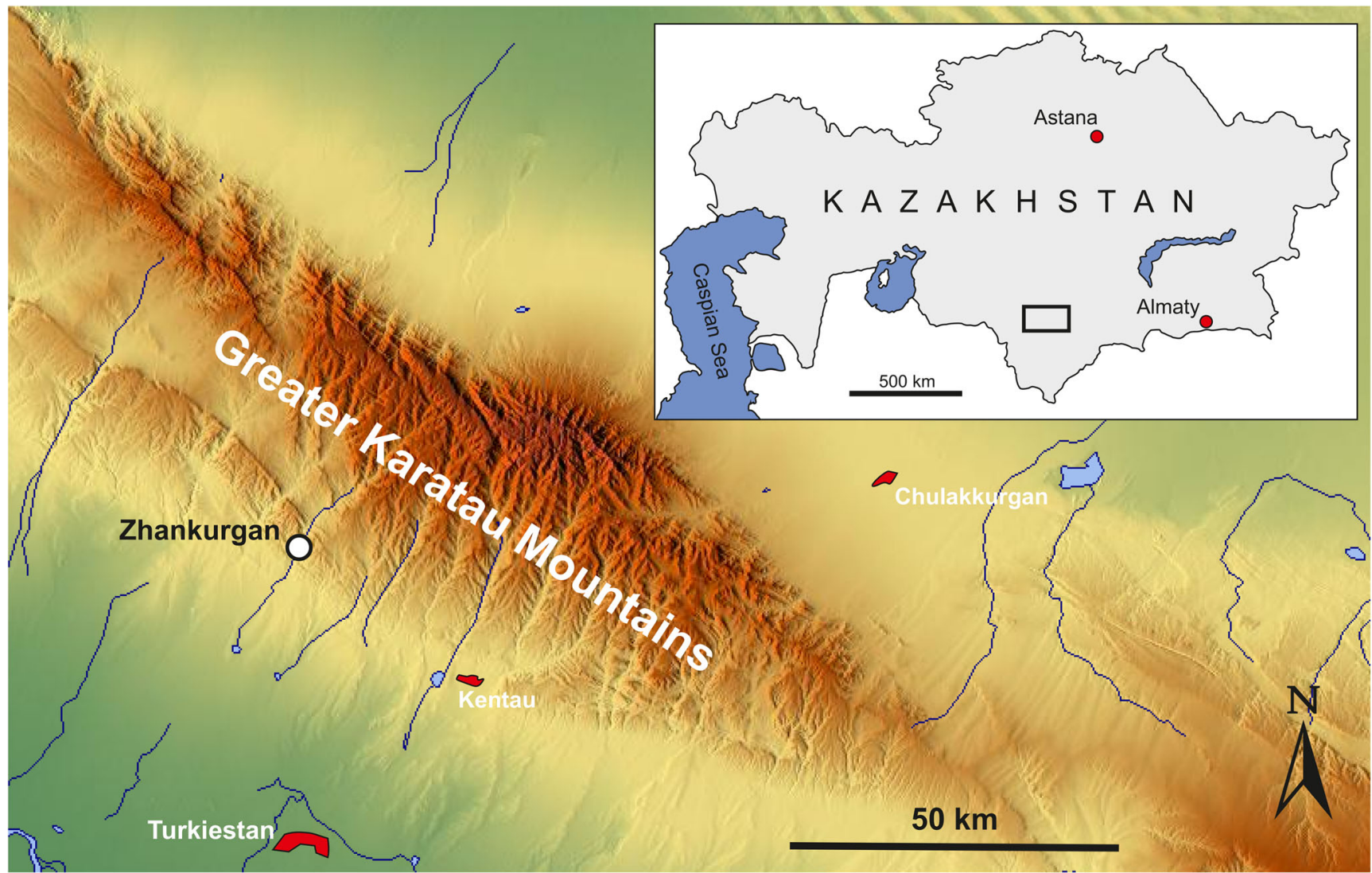

Fig. 1 Relief map of the Greater Karatau Mountains to show the location of the Zhankurgan section. Inset shows the location of the Greater Karatau in Kazakhstan

overall geometry of this platform were structurally controlled by rifted edges, thermal subsidence, local tectonics and relative sea-level fluctuations (Cook et al. 2002). In comparison to similar Palaeozoic depositional systems, the Greater Karatau carbonate platform was unique because numerous, large mud mounds developed on its seaward margin and on the upper slope, within six stratigraphic levels (Zempolich et al. 2002).

The Carboniferous sedimentary succession of the Greater Karatau comprises various carbonates deposited in basin-plain, slope, platform-margin and platforminterior settings (Cook et al. 2002). The investigated Viséan succession of the Zhankurgan section is several $100 \mathrm{~m}$ thick and composed of mudstones and shales intercalated with layers of allodapic limestones (grainstone and packstone in texture) and carbonate debrites (Fig. 2). It belongs to the Baktysai Formation and represents deepwater facies sediments formed in a slope environment. The interbeds contain allochthonous bioclastic material derived predominantly from shallow-water areas of the carbonate platform (Zhaimina et al. 2014). In contrast, the mudstones are rich in radiolarians and sponge spicules.

\section{Palaeogeographic position of the Goniatites assemblage in the Greater Karatau}

Late Viséan to earliest Serpukhovian ammonoids are known from only a few regions in Central Asia:

Kazakhstan: Librovitch (1940) described Viséan ammonoid assemblages from four regions in Kazakhstan: (1) Qaraghandy Province (Karaganda Oblast' in the older literature)-specimens of Beyrichoceras and Bollandoceras from the Ashchi-Su basin. (2) Semey Province (Semipalatinsk Oblast' in the older literature) - a single occurrence of Lusitanoceras orientale from Ak-Dzhal. (3) Kokpekty Province (Kokpektinskaya Oblast' in the older literature)Lusitanoceras orientale from Pokpekty Mountain. (4) Priirtysh region-Lusitanoceras orientale and Lusitanoceras irtyshense from the area of the Tarankul' Lake.

According to the ammonoid assemblages, two stratigraphic horizons are represented. The Qaraghandy assemblage may have an early Late Viséan age; the cooccurrence of Beyrichoceras and Bollandoceras is the characteristic for the late Asbian of the British regional stratigraphy (Bisat 1934; Korn and Tilsley 2006). In the 


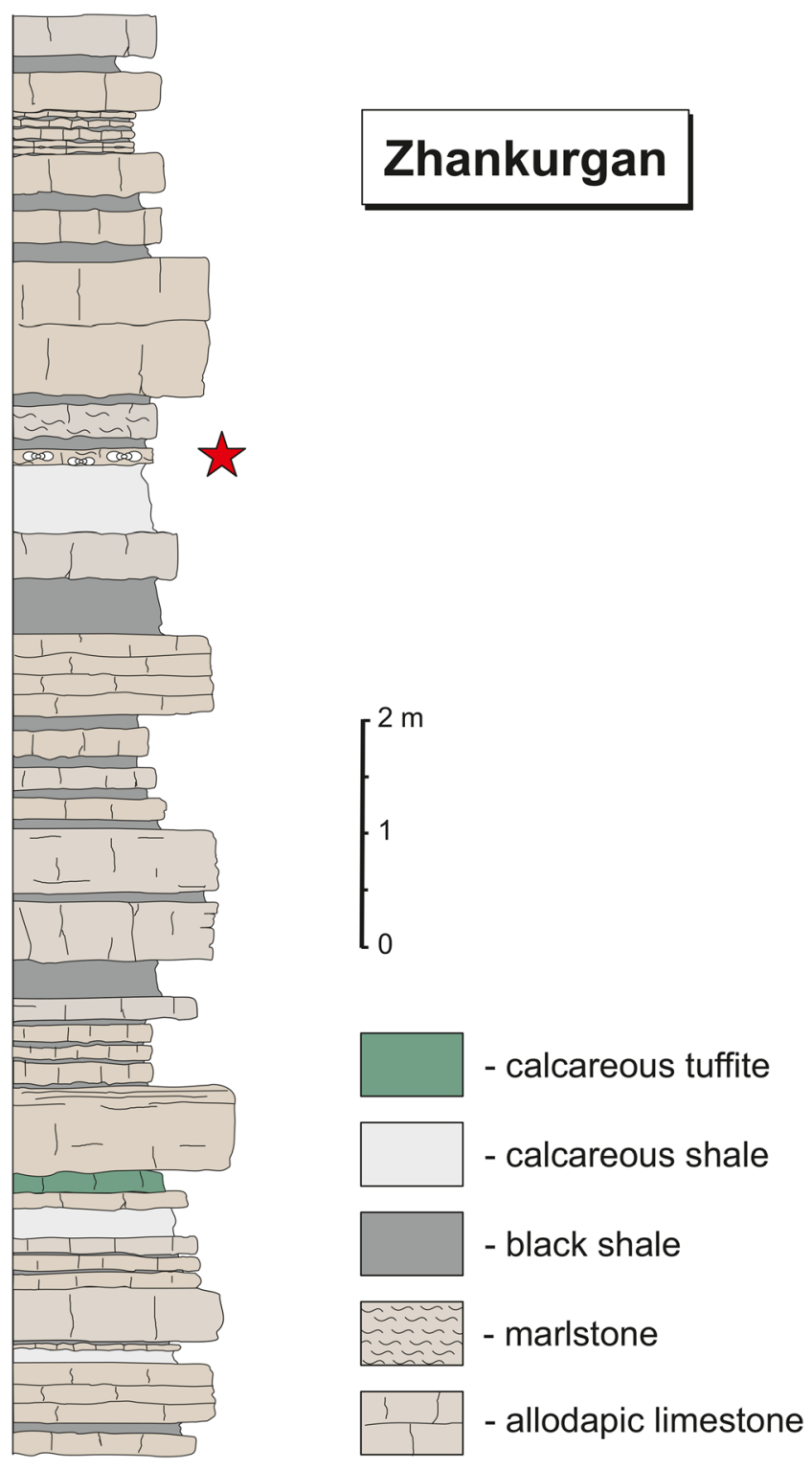

Fig. 2 Detailed lithological column of the middle part of the Viséan succession in the Zhankurgan section. The Goniatites-bearing layer is asterisked

European occurrences, however, ammonoid assemblages of this age regularly contain specimens of Goniatites.

The other three occurrences with Lusitanoceras orientale, which was attributed to the genus Goniatites by Librovitch (1940), are stratigraphically younger. Lusitanoceras orientale closely resembles the species L. poststriatum (Brüning 1923), L. algarviense (Pereira De Sousa 1923) and L. zirari Korn and Ebbighausen 2008 from Central and South-Western Europe as well as the Hercynian part of North Africa; most probably it indicates a Late Viséan to the earliest Serpukhovian age. In North-Western Ireland and in the Rhenish Mountains, Lusitanoceras species occur in beds at the base of the Lochriea ziegleri Zone (Barham et al. 2014; Wang et al. 2018).
China: Rich occurrences of Late Viséan and early Serpukhovian ammonoids were described by Liang and Wang (1991) from near the Kalajila village in northern Xinjiang. From the lowest of four successive horizons with ammonoids, three species of Goniatites were reported to cooccur with Arcanoceras and Prolecanites, followed by a horizon with Hibernicoceras, Junggarites, Kalajilalites and Praedaraelites, a third horizon with Dombarites and Neogoniatites and a fourth horizon with Dombarites and Platygoniatites. It is by far the best latest Viséan-early Serpuhukhovian ammonoid succession known from east of the Urals.

When compared with other regions, the lower two ammonoid occurrences have a Late Viséan age and the younger two belong in the early Serpukhovian. Goniatites and Hibernicoceras are typical genera of the Late Viséan succession in Ireland, the Rhenish Mountains, South Portugal and the Hercynian part of North Africa (Moore and Hodson 1958; Korn 1988, 1997a; Korn and Horn 1997; Korn and Ebbighausen 2008).

Dombarites, Neogoniatites and Platygoniatites are characteristic early Serpukhovian genera, which occur in the South Urals (Dombar Hills in north-western Kazakhstan and Verkhnyaya Kardailovka in South Russia) in beds belonging to the Lochriea ziegleri Zone (Nikolaeva et al. 2009; Nikolaeva 2013; Nikolaeva and Konovalova 2017).

This review shows that the new record of Goniatites in the Greater Karatau is almost a unique occurrence in the entire Central Asian region. A look at the composition of the assemblage makes clear that the Zhankurgan assemblage is speciespoor with only two representatives of Goniatites. Goniatites is in other regions accompanied by other genera of the families Girtyoceratidae, Pericyclidae, Nomismoceratidae etc., all of which are missing in the newly found assemblage. It is interesting, however, that these two species represent the margins of the morphological range with respect to conch geometry. Whilst $G$. zhankurganensis has, even at a conch diameter of more than $40 \mathrm{~mm}$, a nearly ball-shaped conch (width-diameter ratio of more than 0.90$), G$. zhankurganensis is much slenderer with a width-diameter ratio of only 0.50 . Whilst the first is amongst the stoutest species of Goniatites, the latter is the slenderest. A wide range of morphospace has been found in an almost time equivalent assemblage in the AntiAtlas of Morocco, but this assemblage contains Goniatites cooccurring with other ammonoids (Klug et al. 2016).

\section{Material}

The investigated section is located in the southwestern part of the Greater Karatau Mountains (43.6452 ${ }^{\circ} \mathrm{N} ; 68.2133^{\circ} \mathrm{E}$ ). The material comes from the Baktysai Formation, which is underlain by Waulsortian bioherms and was dated using 
foraminifera Early Viséan to Serpukhovian (Zhaimina et al. 2017, p. 49). The Baktysai Formation crops out along the Zhankurgan River, about $2.5 \mathrm{~km}$ north of the Abai village. In the middle part of the succession, exposed on the southern flank of the valley, one of the numerous marlstone layers contained numerous specimens of Goniatites (Fig. 3).

A total of 23 specimens have been studied, and 14 of these can be attributed to the new species. All of them are deformed to some degree. Most of the phragmocones are partly crushed and in all specimens, the body chamber is nearly completely squashed. The phragmocone chambers are usually filled with calcite. The material is stored in the fossil cephalopod collection of the Museum für Naturkunde Berlin under the catalogue numbers MB.C.29201 to MB.C.29203.

\section{Systematic descriptions (DK and ZB)}

Superfamily Goniatitoidea de Haan, 1825

Family Goniatitidae de Haan, 1825
Genus Goniatites de Haan, 1825

Goniatites zhankurganensis n. sp.

(Figs. 4a-c, 5a)

Etymology: Named after the type locality at the Zhankurgan River.

Holotype: Specimen MB.C.29201.1, illustrated in Fig. 4a.

Type locality and horizon: Zhankurgan River bank, $2.5 \mathrm{~km}$ north of the Abai village (Greater Karatau, Kazakhstan); Baktysai Formation (Late Viséan).

Material: Ten specimens (MB.C.29201.1-10).

Diagnosis: Species of Goniatites with spindle-shaped conch in the early juvenile stage and globular conch between 15 and $40 \mathrm{~mm}$ diameter $(\mathrm{ww} / \mathrm{dm}=0.95-1.00)$. Umbilicus moderate in early ontogeny ( $u w / d m=0.20-0.30)$ and very narrow in all stages larger than $4 \mathrm{~mm}$ diameter ( $\mathrm{uw} / \mathrm{dm}$ around 0.10 ). Umbilical wall slightly incurved in late growth stages. Aperture very low (WER $=1.45$ ) at $40 \mathrm{~mm}$ diameter. Suture line at $36 \mathrm{~mm}$ conch diameter with very narrow or narrow external lobe $(0.60$ of the external lobe depth; 1.25 of the

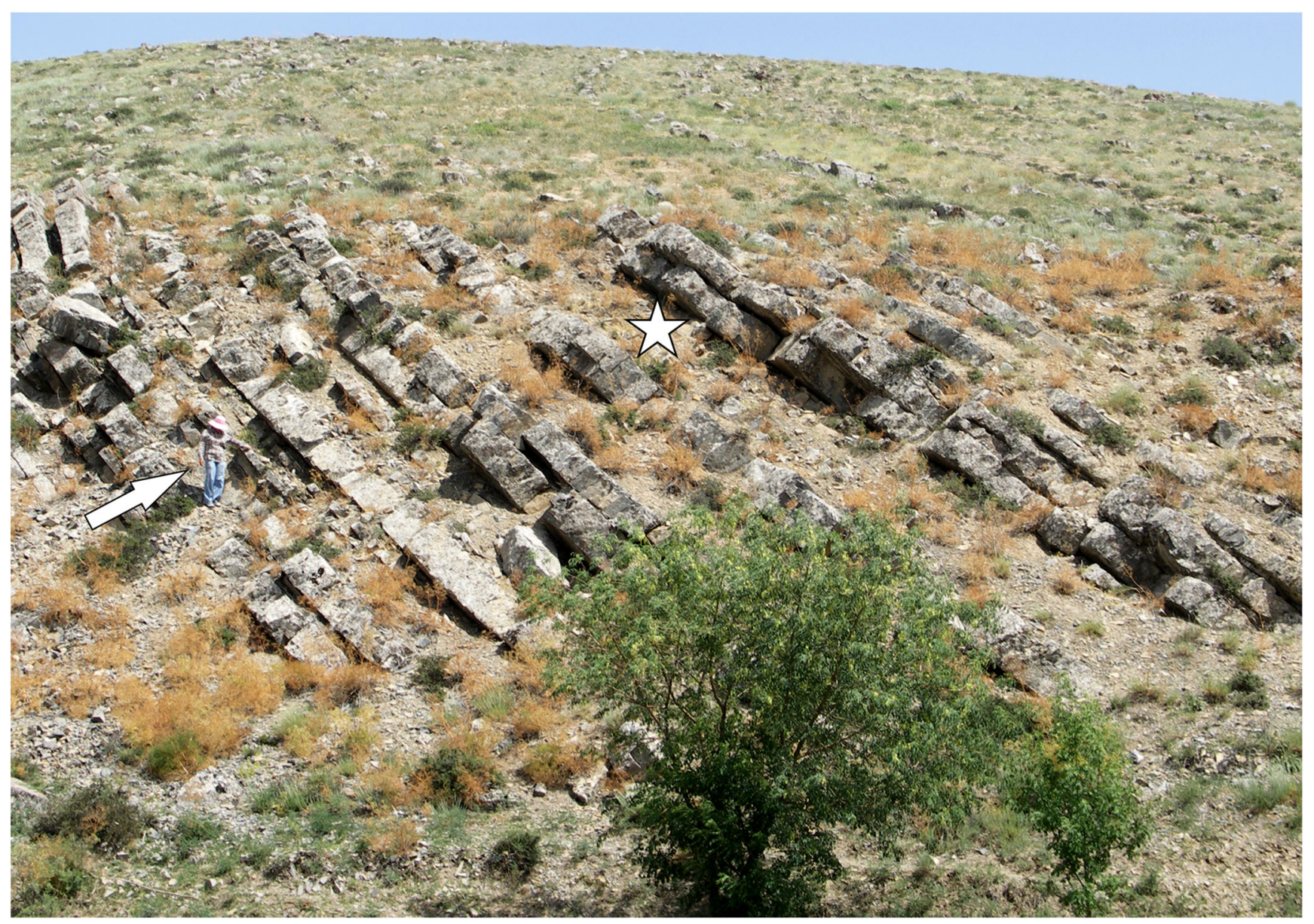

Fig. 3 Looking southeast at the middle part of the Viséan succession in the Zhankurgan section. The Goniatites-bearing layer is asterisked, person for scale 

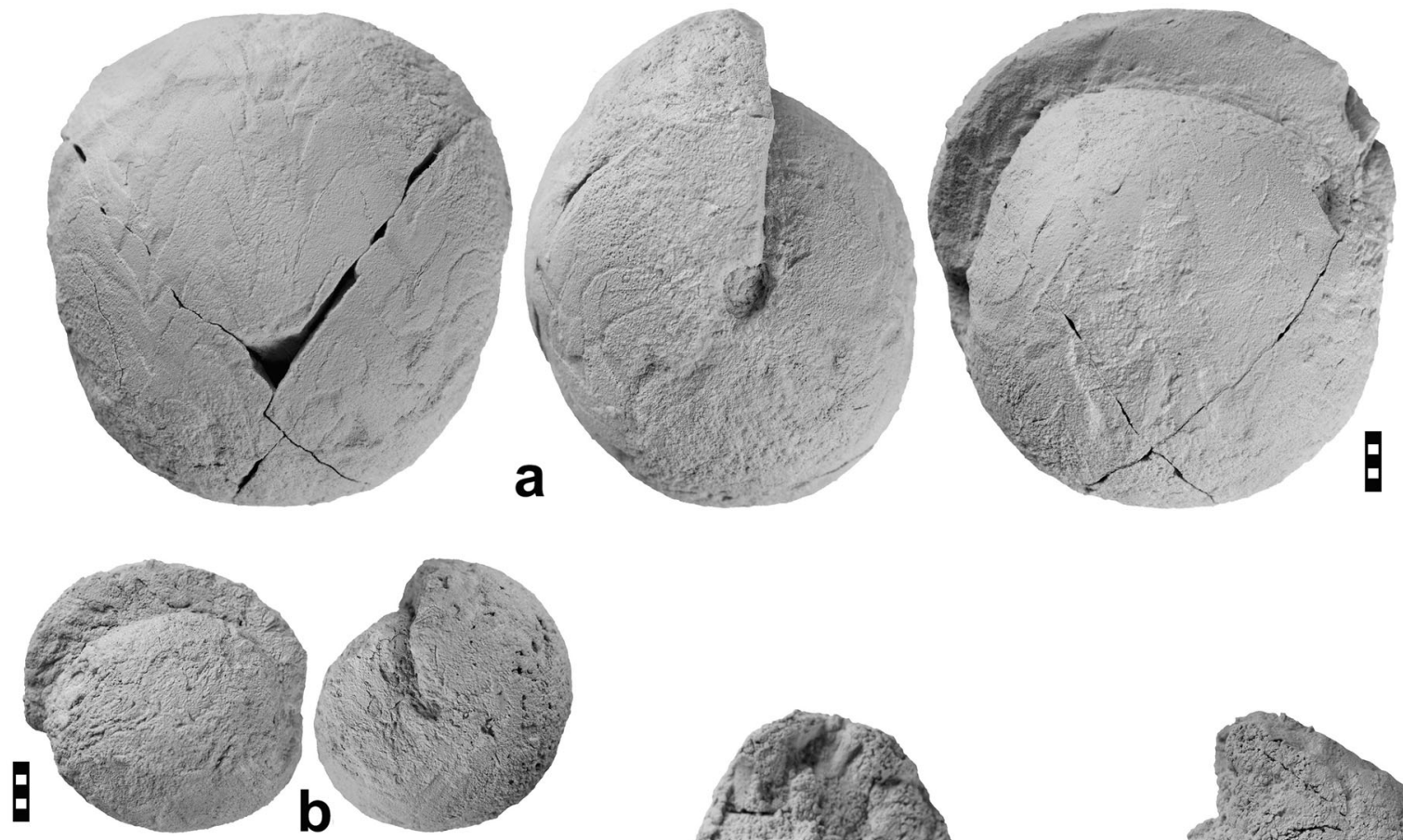
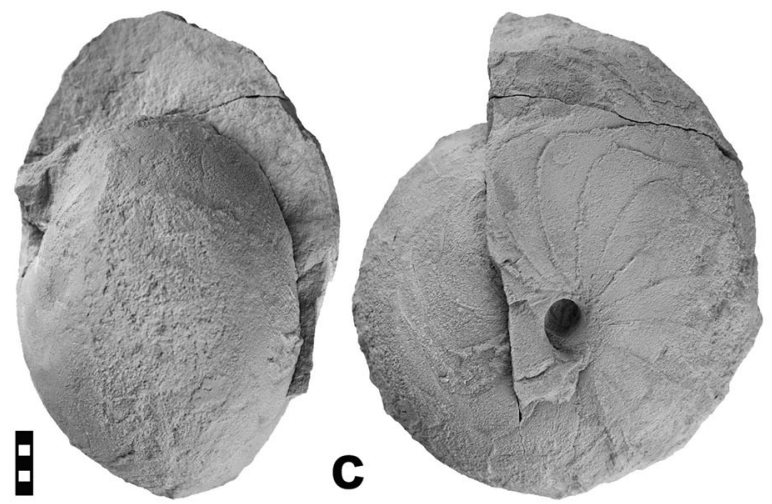

Fig. 4 Ammonoids from the Zhankurgan section, Greater Karatau, Kazakhstan. a Goniatites zhankurganensis n. sp., holotype MB.C.29201.1. b Goniatites zhankurganensis n. sp., paratype

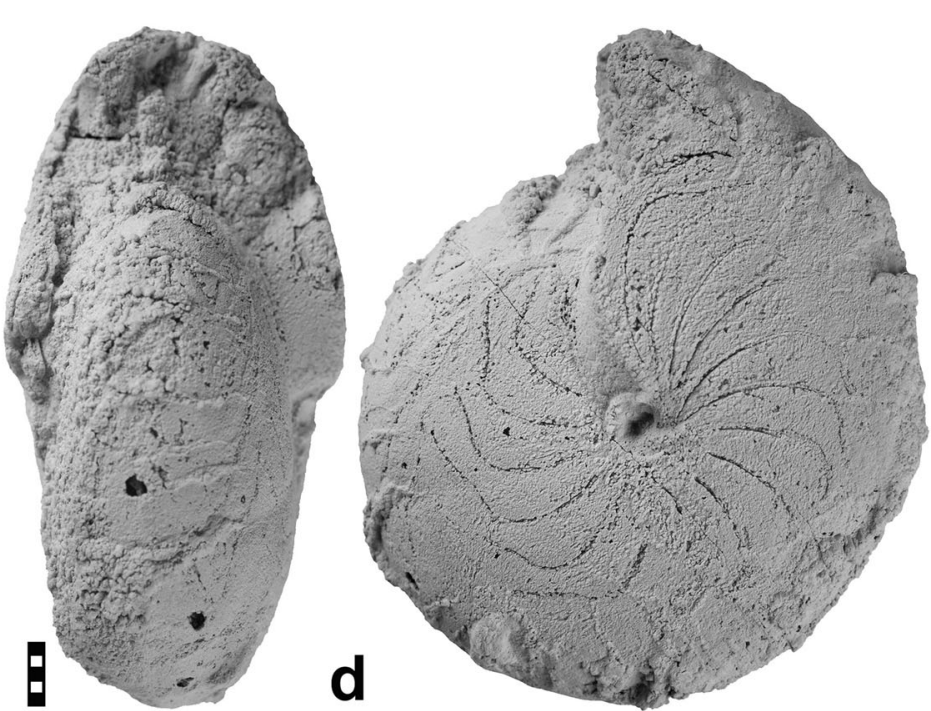

MB.C.29201.2. c Goniatites zhankurganensis n. sp., paratype MB.C.29201.3. d Goniatites abaiensis n. sp., holotype MB.C.29202.1. Scale bar units, $1 \mathrm{~mm}$ ventrolateral saddle width), and low median saddle ( 0.40 of the external lobe depth). External lobe V-shaped with weakly sinuous flanks and very narrow, V-shaped prongs, ventrolateral saddle bluntly acute.

Description: Holotype MB.C.29201.1 has, at $42 \mathrm{~mm}$ conch diameter, nearly the shape of a ball $(\mathrm{ww} / \mathrm{dm}=0.93)$. It is slightly deformed, but this did not affect the ww/dm ratio (Fig. 4a). The fully septate specimen is involute $(\mathrm{ww} / \mathrm{dm}=$ 0.07 ) with a rounded umbilical wall, a broadly rounded venter and a very low aperture $(\mathrm{WER}=1.45)$. It shows two shallow and wide steinkern constrictions, which extend nearly linearly across flanks and venter. Shell remains are not preserved.

The suture line of the holotype has a V-shaped external lobe with sinuous flanks, very narrow prongs and a median saddle that has 0.40 the height of the E lobe depth (Fig. 5b). The ventrolateral saddle is weakly asymmetric and subacute, and the adventive lobe is weakly asymmetric with convexly curved flanks, of which the dorsal flank is slightly more convex.

The smaller paratype MB.C.29201.2 (23 mm dm) is poorly preserved and only allows the study of the conch geometry (Fig. 4b). It is also globular and involute (ww/dm $=1.05$; uw/ $\mathrm{dm}=0.05)$ with a low coiling rate $(\mathrm{WER}=1.55)$ (Tables 1 and 2). Paratype MB.C.29201.3 (Fig. 4c) with 42 mm conch diameter is laterally deformed (and thus appears to be more compressed).

The sectioned paratype MB.C.29201.4 is deformed and partly crushed but allows an insight in the conch ontogeny 

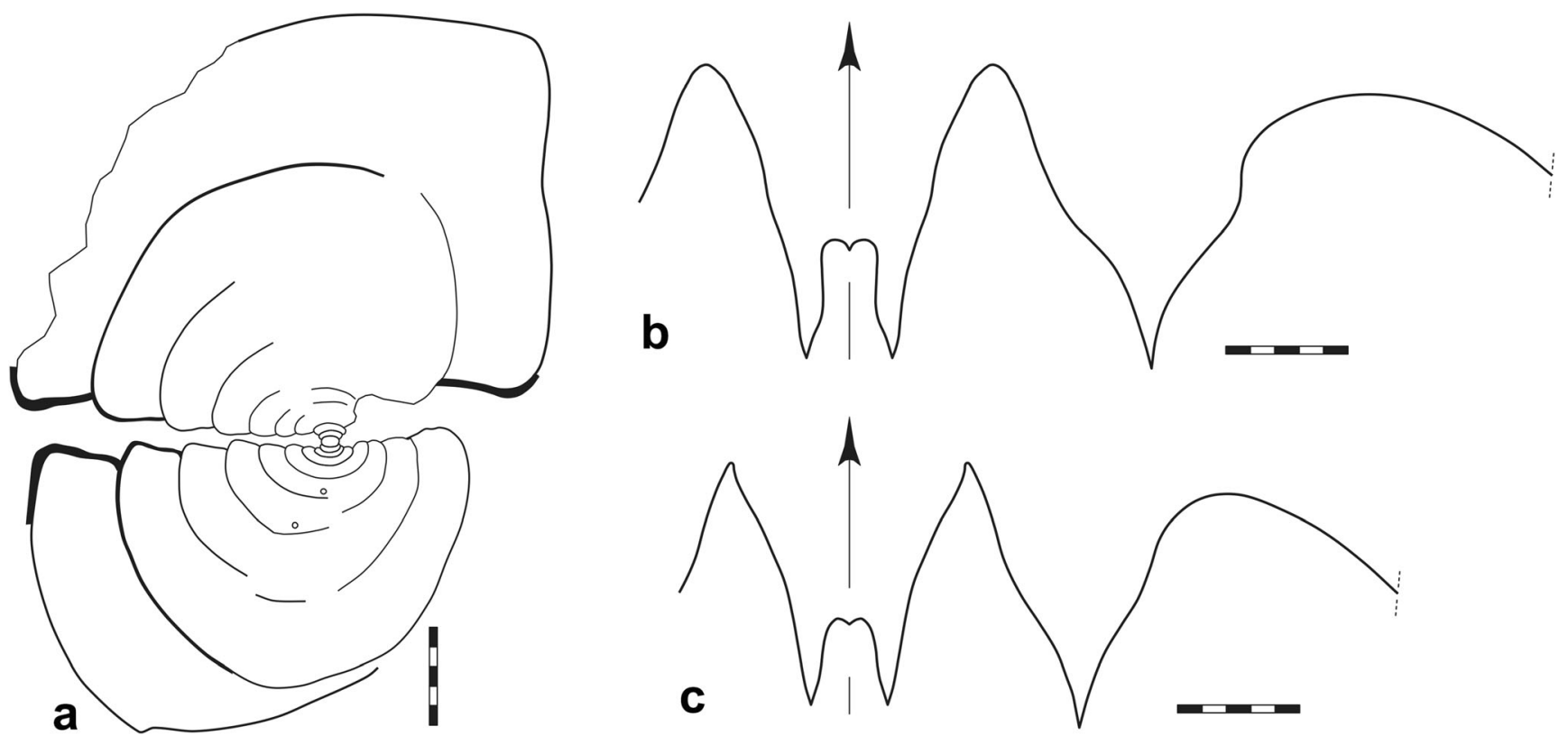

Fig. 5 Ammonoids from the Zhankurgan section, Greater Karatau, Kazakhstan. a Goniatites zhankurganensis n. sp., cross section of paratype MB.C.29201.4. b Goniatites zhankurganensis n. sp., sutures

(Fig. 5a). It had about $40 \mathrm{~mm}$ conch diameter and had a globular form. The initial stage is still quite intact and shows two weakly embracing, subevolute volutions with crescent-shaped whorl profile. The conch is spindle-shaped (ww/dm ca. 1.20) at about $2 \mathrm{~mm}$ diameter and becomes slenderer during ontogeny. It can be estimated that, at $15 \mathrm{~mm} \mathrm{dm}$, it is nearly perfectly ball-shaped. Although partly crushed, the cross section shows the shape of the umbilical margin and the umbilical wall. Above a conch diameter of about $8 \mathrm{~mm}$, the umbilical margin tends to become pronounced and the umbilical wall gets a sinuous, slightly incurved section.

Discussion: Goniatites zhankurganensis is a species that has a marginal morphological position within the genus Goniatites because of its very stout conch. Most of the other species of the genus are much slenderer at a comparative diameter. Whilst the instance, range between 0.70 and 0.75 (at $40 \mathrm{~mm}$ diameter), G. zhankurganensis is much stouter with a ww/dm ratio of 0.95 . The same is true for the North American species G. americanus (see Korn and Titus 2011) and the North African species G. rodioni and G. tympanus (see Klug et al. 2006; Korn et al. 2007), which reach a ww/dm ratio of only $0.75-0.80$ at $40 \mathrm{~mm}$ conch diameter. In its conch dimension, $G$. zhankurganensis has the appearance of a neotenic species that maintains the stout juvenile conch morphology in the larger growth stage. stoutest conchs seen in the European species G. sphaericus, for
Table 1 Conch proportions of Goniatites zhankurganensis n. sp.

\begin{tabular}{llll}
\hline $\mathrm{dm}$ & Conch shape & Whorl cross section shape & Whorl expansion \\
\hline $25 \mathrm{~mm}$ & Globular; involute & Strongly depressed; very strongly embracing & Low \\
& $($ ww $/ \mathrm{dm} \sim 1.05 ; \mathrm{uw} / \mathrm{dm} \sim 0.05)$ & $(\mathrm{ww} / \mathrm{wh} \sim 1.95 ;$ IZR $\sim 0.65)$ & $($ WER $\sim 1.55)$ \\
\multirow{2}{*}{$40 \mathrm{~mm}$} & Globular; involute & Strongly depressed; very strongly embracing & Very low \\
& $(\mathrm{ww} / \mathrm{dm} \sim 0.95 ; \mathrm{uw} / \mathrm{dm} \sim 0.07)$ & $(\mathrm{ww} / \mathrm{wh} \sim 1.75 ;$ IZR $\sim 0.65)$ & $(\mathrm{WER} \sim 1.45)$ \\
\hline
\end{tabular}

Table 2 Conch measurements of Goniatites zhankurganensis n. sp.

\begin{tabular}{lcccccccccc}
\hline & dm & ww & wh & uw & ah & $\begin{array}{c}\text { ww/ } \\
\mathrm{dm}\end{array}$ & $\begin{array}{l}\text { ww/ } \\
\text { wh }\end{array}$ & $\begin{array}{c}\text { uw/ } \\
\mathrm{dm}\end{array}$ & WER & IZR \\
\hline MB.C.29201.1 & 42.1 & 39.4 & 22.3 & 2.8 & 7.2 & 0.93 & 1.76 & 0.07 & 1.45 & 0.68 \\
MB.C.29201.2 & 22.9 & 23.9 & 12.4 & 1.0 & 4.5 & 1.05 & 1.93 & 0.05 & 1.55 & 0.63 \\
MB.C.29201.4 & 2.18 & 2.60 & 0.98 & 0.51 & 0.43 & 1.19 & 2.67 & 0.23 & 1.55 & 0.56 \\
\hline
\end{tabular}


Table 3 Conch proportions of Goniatites abaiensis n. sp.

Table 4 Conch measurements of Goniatites abaiensis n. sp.

\begin{tabular}{llll}
\hline $\mathrm{dm}$ & Conch shape & Whorl cross section shape & Whorl expansion \\
\hline $50 \mathrm{~mm}$ & Thickly discoidal; involute & Weakly depressed; very strongly embracing & Low \\
& $(\mathrm{ww} / \mathrm{dm} \sim 0.50 ; \mathrm{uw} / \mathrm{dm} \sim 0.05)$ & $($ ww/wh $\sim 0.90 ;$ IZR $\sim 0.60)$ & $(\mathrm{WER} \sim 1.65)$ \\
\hline
\end{tabular}

\begin{tabular}{lllllllllll}
\hline & $\mathrm{dm}$ & ww & wh & uw & ah & $\begin{array}{c}\text { ww/ } \\
\mathrm{dm}\end{array}$ & $\begin{array}{c}\text { ww/ } \\
\text { wh }\end{array}$ & $\begin{array}{c}\text { uw/ } \\
\mathrm{dm}\end{array}$ & WER & IZR \\
\hline MB.C.29202.1 & 53.2 & 26.8 & 29.5 & 2.9 & 11.5 & 0.50 & 0.91 & 0.05 & 1.63 & 0.61 \\
\hline
\end{tabular}

Goniatites abaiensis n. sp.

(Figs. 4d, 5c)

Etymology: Named after the type locality north of the Abai village.

Holotype: Specimen MB.C.29202.1, illustrated in Fig. 4d. Type locality and horizon: Zhankurgan River bank, $2.5 \mathrm{~km}$ north of the Abai village (Greater Karatau, Kazakhstan); Baktysai Formation (Late Viséan).

Material: Four specimens (MB.C.29202.1-4).

Diagnosis: Species of Goniatites with thickly discoidal conch at $50 \mathrm{~mm}$ diameter $(\mathrm{ww} / \mathrm{dm}=0.50)$, umbilicus very narrow (uw/dm =0.05). Aperture low $(\mathrm{WER}=1.60)$ at $50 \mathrm{~mm}$ diameter. Suture line at $36 \mathrm{~mm}$ conch diameter with very narrow or narrow external lobe ( 0.55 of the external lobe depth; 1.25 of the ventrolateral saddle width), and low median saddle ( 0.33 of the external lobe depth). External lobe weakly Y-shaped with very narrow, V-shaped prongs, ventrolateral saddle acute.

Description: Holotype MB.C.29202.1 is a fully septate specimen of $53 \mathrm{~mm}$ phragmocone diameter (Fig. 4d). It is thickly discoidal and involute $(\mathrm{ww} / \mathrm{dm}=0.50 ; \mathrm{ww} / \mathrm{dm}=0.05)$ with low coiling rate $(\mathrm{WER}=1.63)$. The whorl profile is the widest at the rounded umbilical margin, from where the flanks converge towards the continuously rounded venter.

The suture line of the holotype is typical for Goniatites (Fig. 5c). The external lobe is V-shaped with weakly concave flanks, the prongs of this lobe are narrowly $\mathrm{V}$ shaped, and the median saddle has 0.33 the height of the E lobe depth. The ventrolateral saddle is acute, and the adventive lobe is nearly symmetric with weakly convex flanks.

Discussion: Goniatites abaiensis is characterised by the very slender conch (ww/dm $\sim 0.50$ at $50 \mathrm{~mm} \mathrm{dm}$ ) and in this character, it is different from all other species of the genus. A species with comparatively slender conch and a similar suture line is $G$. crenistria, but even in this species, the ww/dm ratio is $0.60-0.65$ at $50 \mathrm{~mm}$ conch diameter (Tables 3 and 4).
Acknowledgements Open Access funding provided by Projekt DEAL. We acknowledge the rock preparation of the specimens by Markus Brinkmann (MfN Berlin). We are also indebted to Alan Titus (Kanab) and David Work (Augusta) for their critical reviews of the manuscript.

Funding information Financial support for this study was provided by the Polish National Science Centre, grant No. 2013/11/B/ST10/04751.

\section{Compliance with ethical standards}

Conflict of interest The authors declare that they have no conflicts of interest.

Open Access This article is licensed under a Creative Commons Attribution 4.0 International License, which permits use, sharing, adaptation, distribution and reproduction in any medium or format, as long as you give appropriate credit to the original author(s) and the source, provide a link to the Creative Commons licence, and indicate if changes were made. The images or other third party material in this article are included in the article's Creative Commons licence, unless indicated otherwise in a credit line to the material. If material is not included in the article's Creative Commons licence and your intended use is not permitted by statutory regulation or exceeds the permitted use, you will need to obtain permission directly from the copyright holder. To view a copy of this licence, visit http://creativecommons.org/licenses/by/4.0/.

\section{References}

Abrajevitch, A., Van der Voo, R., Bazhenov, M. L., Levashova, N. M., \& McCausland, P. J. (2008). The role of the Kazakhstan orocline in the late Paleozoic amalgamation of Eurasia. Tectonophysics, 455(1-4), 61-76. https://doi.org/10.1016/j.tecto.2008.05.006.

Alexeiev, D. V., Cook, H. E., Buvtyshkin, V. M., \& Golub, L. Y. (2009). Structural evolution of the Ural-Tian Shan junction: A view from Karatau ridge, South Kazakhstan. Comptes Rendus Geoscience, 341(2-3), 287-297. https://doi.org/10.1016/j.crte.2008.12.004.

Alexeiev, D. V., Cook, H. E., Djenchuraeva, A. V., \& Mikolaichuk, A. V. (2017). The stratigraphic, sedimentological and structural evolution of the southern margin of the Kazakhstan continent in the Tien Shan Range during the Devonian to Permian. Geological Society, London, Special Publications, 427(1), 231-269. https://doi.org/ 10.1144/sp427.3 .

Barham, M., Murray, J., Sevastopulo, G., \& Williams, D. M. (2014). Conodonts of the genus Lochriea in Ireland and the recognition of 
the Viséan-Serpukhovian (Carboniferous) boundary. Lethaia, 48(2), 151-171. https://doi.org/10.1111/let.12096 .

Bisat, W. S. (1934). The goniatites of the Beyrichoceras zone in the north of England. Proceedings of the Yorkshire Geological Society, 22, 280-309.

Biske, Y. S., \& Seltmann, R. (2010). Paleozoic Tian-Shan as a transitional region between the Rheic and Urals-Turkestan oceans. Gondwana Research, 17(2-2), 602-613. https://doi.org/10.1016/j.gr.2009.11.014.

Bogoslovskaya, M. F. (1966). Rod Goniatites i ego predstavateli na Yuzhnom Urale. Paleontologicheskiy Zhurnal, 1966(1), 38-46.

Brüning, K. (1923). Beiträge zur Kenntnis des Rheinisch-westfälischen Unterkarbons, insbesondere der Goniatiten und Korallen in der stratigraphischen Stellung und Gliederung. Marburg.

Campbell, K. S. W., Brown, D. A., \& Coleman, A. R. (1983). Ammonoids and the correlation of the lower Carboniferous rocks of eastern Australia. Alcheringa, 7(2), 75-123.

Cook, H. E., Zhemchuzhnikov, V. G., Zempolich, W. G., Zhaimina, V. Y., Buvtyshkin, V. M., Kotova, E. A., et al. (2002). Devonian and Carboniferous carbonate platform facies in the Bolshoi Karatau, southern Kazakhstan: outcrop analogs for coeval carbonate oil and gas fields in the North Caspian Basin, Western Kazakhstan. Special Publication - Society for Sedimentary Geology, 74, 81-122.

Drahovzal, J. (1972). The Lower Carboniferous ammonoid genus Goniatites. In 1968 Proceedings of the International Paleontological Union, XIII International Geological Congress, Prague, Czechoslovakia, Section, 15-52.

Filippova, I. B., Bush, V. A., \& Didenko, A. N. (2001). Middle Paleozoic subduction belts: the leading factor in the formation of the Central Asian fold-and-thrust belt. Russian Journal of Earth Sciences, 3(3), 405-426.

Gordon, M. Jr. (1957). Mississippian cephalopods of northern and eastern Alaska. Professional Papers, U.S. Geological Survey, 283, 1-61.

Gordon, M. Jr. (1965). Carboniferous cephalopods of Arkansas. Professional Papers, U.S. Geological Survey, 460, 1-322.

Haan, G. de (1825). Monographia Ammoniteorum et Goniatiteorum. Lugduni Batavorum: Hazenberg.

Klug, C., Döring, S., Korn, D., \& Ebbighausen, V. (2006). The Visean sedimentary succession at the Gara el Itima (Anti-Atlas, Morocco) and its ammonoid faunas. Fossil Record, 9, 3-60.

Klug, C., De Baets, K., \& Korn, D. (2016). Exploring the limits of morphospace: ontogeny and ecology of late Visean ammonoids from the Tafilalt, Morocco. Acta Palaeontologica Polonica, 61(1), 1-14. https://doi.org/10.4202/app.00220.2015.

Korn, D. (1988). Die Goniatiten des Kulmplattenkalkes (Cephalopoda, Ammonoidea; Unterkarbon; Rheinisches Schiefergebirge). Geologie und Paläontologie in Westfalen, 11, 1-293.

Korn, D. (1997a). Evolution of the Goniatitaceae and Visean-Namurian biogeography. Acta Palaeontologica Polonica, 42, 177-199.

Korn, D. (1997b). The Palaeozoic ammonoids of the South Portuguese Zone. Memorias do Instituto geologico e Mineiro, 33, 1-131.

Korn, D. (2017). Goniatites sphaericus (Sowerby, 1814), the archetype of Palaeozoic ammonoids: a case of decreasing phenotypic variation through ontogeny. PalZ, 91(3), 337-352.

Korn, D., \& Ebbighausen, V. (2008). The Early Carboniferous (Mississippian) ammonoids from the Chebket el Hamra (Jerada Basin, Morocco). Fossil Record, 11, 83-156.

Korn, D., \& Horn, K. (1997). The Late Visean (Early Carboniferous) goniatite stratigraphy in the South Portuguese Zone, a comparison with the Rhenish Massif. Newsletters on Stratigraphy, 35, 97-113.

Korn, D., \& Tilsley, J. W. (2006). Ammonoid assemblages from the Asbian B-2b (Early Carboniferous: Mississippian) buildups of the Peak District, England. Proceedings of the Yorkshire Geological Society, 56, 111-150.

Korn, D., \& Titus, A. L. (2011). Goniatites Zone (middle Mississippian) ammonoids of the Antler Foreland Basin (Nevada, Utah). Bulletin of Geosciences, 86(1), 107-196. https://doi.org/10.3140/bull.geosci.1242.
Korn, D., Bockwinkel, J., \& Ebbighausen, V. (2007). Tournaisian and Visean ammonoid stratigraphy in North Africa. Neues Jahrbuch für Geologie und Paläontologie, Abhandlungen, 243, 127-148.

Korn, D., Titus, A. L., Ebbighausen, V., Mapes, R. H., \& Sudar, M. N. (2012). Early Carboniferous (Mississippian) ammonoid biogeography. Geobios, 45(1), 67-77. https://doi.org/10.1016/j.geobios.2011. 11.013 .

Kullmann, J. (1961). Die Goniatiten des Unterkarbons im Kantabrischen Gebirge (Nordspanien). I. Stratigraphie. Paläontologie der U.O. Goniatitina Hyatt. Neues Jahrbuch für Geologie und Paläontologie, Abhandlungen, 113, 219-326.

Liang, X., \& Wang, M. (1991). Carboniferous cephalopods of Xinjiang. Palaeontologia Sinica, Series B, 180, 1-171.

Librovitch, L. S. (1940). Ammonoidea iz kamennougolnykh otlozheniy Severnogo Kazakhstana. Paleontologiya SSSR, 4(91), 1-395.

Moore, E. W. J., \& Hodson, F. (1958). Goniatites from the Upper Viséan shales of County Leitrim, Eire. Liverpool and Manchester Geological Journal, 2, 86-105.

Nikolaeva, S. V. (2013). New Viséan and Serpukhovian ammonoids from the Verkhnyaya Kardailovka section, eastern slope of the South Urals. Paleontological Journal, 47(4), 386-399.

Nikolaeva, S. V., \& Konovalova, V. A. (2017). New Late Viséan and Early Serpukhovian ammonoids in the Verkhnyaya Kardailovka section (eastern slope of the South Urals). Paleontological Journal, 51(7), 715-726.

Nikolaeva, S. V., Akhmetshina, L. Z., Konovalova, V. A., Korobkov, V. F., \& Zainakaeva, G. F. (2009). The Carboniferous carbonates of the Dombar Hills (western Kazakhstan) and the problem of the ViséanSerpukhovian boundary. Palaeoworld, 18(2-3), 80-93.

Pereira De Sousa, F. L. (1923). Sur un nouveau genre de Goniatite: Lusitanoceras. Bulletin de la Societe Geologique de France, 423, 304.

Skompski, S., Paszkowski, M., Krobicki, M., Kokovin, K., Korn, D., \& Wrzolek, T. A. (2001). Depositional setting of the Devonian/ Carboniferous biohermal Bol'shaya Nadota Carbonate Complex, Subpolar Urals. Acta Geologica Polonica, 51, 217-235.

Wang, Q., Korn, D., Nemyrovska, T., \& Qi, Y. (2018). The Wenne river bank section - An excellent section for the Viséan-Serpukhovian boundary based on conodonts and ammonoids (Mississippian; Rhenish Mountains, Germany). Newsletters on Stratigraphy, 51(4), 427-444. https://doi.org/10.1127/nos/2018/0440.

Worthington, J. R., Kapp, P., Minaev, V., Chapman, J. B., Mazdab, F. K., Ducea, M. N., et al. (2017). Birth, life, and demise of the Andeansyn-collisional Gissar arc: Late Paleozoic tectono-magmaticmetamorphic evolution of the southwestern Tian Shan, Tajikistan. Tectonics, 36(10), 1861-1912. https://doi.org/10.1002/ $2016 \mathrm{tc} 004285$

Zempolich, W. G., Cook, H. E., Zhemchuzhnikov, V. G., Zhaimina, V., Zorin, A. Y., Buvtyshkin, V. M., et al. (2002). Biotic and abiotic influence on the stratigraphic architecture and Diagenesis of middle to upper Paleozoic carbonates of the Bolshoi Karatau Mountains, Kazakhstan and the Southern Urals, Russia. Special Publication Society for Sedimentary Geology, 74, 123-180.

Zhaimina, V. J., Mustapaeva, S. N., Baybatsha, A. B., \& Belka, Z. (2014). The Viséan- Serpukhovian boundary in the Big Karatau Mountains (South Kazakhstan). Newsletter on Carboniferous Stratigraphy, 31, 51-63.

Zhaimina, V.Y., Buvtyshkin, V.M., Fazylov, E.M., Musina, E.S., Shabalina, L.V. \& Prihodko, D.V. (2017). Upper Devonian Carboniferous reefs buildups of the Bolshoi Karatau Mountains (South Kazakhstan). Field trip guidebook for the international field meeting of the I.U.G.S. Subcommission on Carboniferous Stratigraphy. Almaty-Turkestan, August 15-22, 2017. Almaty.

Publisher's note Springer Nature remains neutral with regard to jurisdictional claims in published maps and institutional affiliations. 